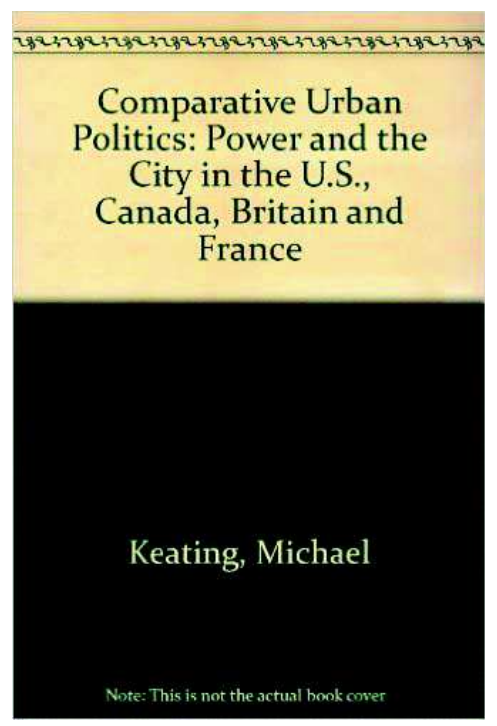

Tomás Antonio Moreira
COMPARATIVE URBAN

POLITICS: POWER AND THE

CITY IN THE U.S., CANADA, BRITAIN AND FRANCE.

KEATiNG, Michael.Lincoln:

Edward Elgar Publishing Limited, I99I, 256P.

\title{
A NECESSIDADE DE UM CONCEITO AMPLIADO DE ESPAÇO PÚBLICO DENTRO DE UM SISTEMA DE VALORES COLETIVOS
}

Professor de Ciências Políticas na Universidade de Western Ontario, Micheal Keating se propõe a examinar o lugar do poder local em um contexto de crescente complexidade das sociedades modernas. Por meio de um estudo comparativo de quatro governos locais nos países industrializados (Estados Unidos, Canadá, França e Grã-Bretanha), seu principal objetivo é destacar a capacidade dos governos locais em gerenciar as cidades cada vez mais sujeitas às mudanças econômicas e sociais. Para isso, ele analisa as estruturas e poderes concedidos aos governos dentro de diferentes sistemas econômicos e políticos nacionais. À luz desta questão, ele apontou um segundo objetivo, mais normativo, o da identificação dos fatores que fornecem uma abertura para as políticas urbanas progressistas.

Comparando dois países europeus e dois países americanos Michael Keating sugere um novo olhar, uma vez que os estudos comparativos nesta área estão confinados às discussões regionais. Além disso, ele baseia seu estudo comparativo sobre um quadro tridimensional: a cultura, estrutura e opções políticas.

Keating parte da constatação que a globalização teve o efeito de reduzir a autonomia dos governos eleitos, enquanto as mudanças que estão ocorrendo contribuem para aumentar e diversificar as demandas sociais. Enquanto alguns estipulam a incapacidade crescente de desenvolver políticas urbanas, Keating prefere abordar a questão em termos de governança urbana para gerenciar conflitos e articular políticas públicas. Além disso, considerando que os governos locais estão buscando um caminho intermediário entre as políticas de 
desenvolvimento econômico e políticas de redistribuição social, Keating se interessa pela capacidade de governar as localidades, recuperando a ideia de "Urban Regime", de Clarence N. Stone, que é definida como um conjunto de regras pelas quais as decisões políticas são feitas integrando as estruturas formais e informais, bem como as relações informais das elites políticas e econômicas dentro de uma coalizão de governo. Deste ponto de vista, trata-se, portanto, de avaliar a capacidade de coalizões para resolver problemas e gerir a transformação.

Os diferentes capítulos do livro se referem aos múltiplos fatores que afetam a autoridade urbana em cada um dos países estudados: a organização da estrutura política; políticas urbanas; os interesses econômicos e sociais; a consolidação urbana; as políticas de distribuição; e as políticas de desenvolvimento econômico. Para cada temas são relacionados diferentes conceitos, os quais permitem compreender a dinâmica urbana de cada país. Nesta ótica, o autor elucida as diferenças de culturas urbanas que prevalecem entre os quatro países, que vão desde uma concepção individualista a um coletivista. A estrutura de governo local mostra que o grau de integração ou fragmentação, assim como as responsabilidades políticas variam muito de um país a outro, bem como dentro do mesmo país. No tocante as responsabilidades, as políticas urbanas destes países são vistas sobre dois eixos. O primeiro compreende a mobilização e controle dos recursos. O segundo trata do antagonismo entre a política de produção (crescimento) e a política de distribuição (demanda social). Além disso, Keating examina as inter-relações entre a cidade e o setor privado, bem como as estratégias de desenvolvimento econômicos implementadas.

À luz destes diferentes temas abordados, embora seja difícil de resumir cada uma das políticas urbanas apresentadas, o estudo comparativo mostra notadamente que os EUA, com um sistema de valores mais individualista, o governo local dispõe de uma grande autonomia formal, mas os poderes são limitados em função da grande fragmentação territorial.

O Canadá ilustra certa hibridação das estruturas e das políticas urbanas dos dois continentes, mas Keating aponta a fraca autonomia formal das cidades deste país. Na Grã-Bretanha, os governos locais têm poderes claramente definidos com capacidade de desenvolver políticas que envolvem diferentes níveis de governo. Na França, apesar do caráter centralizador e a fragmentação dos governos locais, este país tem um sistema mais coletivista e a tendência de descentralização favoreceu a expertise local e uma autonomia crescente.

De uma perspectiva regional, parece que os países europeus se beneficiam de um sistema intergovernamental mais integrado que na América do Norte.

Entretanto, em termos mais gerais, a análise apresentada coloca em evidencia o fato que as políticas urbanas são muito influenciadas tanto pelo ambiente econômico como pelas políticas nacionais. No entanto, as políticas de redistribuição locais não são impossíveis, mas requerem uma vontade política, cultural e estrutural para ser viável. Para melhorar o controle do desenvolvimento urbano, a criação de um governo metropolitano pode, em princípio, melhorar a capacidade de gestão das cidades, mas as análises empíricas mostram pontos fracos, incluindo a frágil legitimidade política e a falta de uma solidariedade social metropolitana. No contexto atual, sobre o 
efeito da reestruturação econômica, as cidades conhecem uma recombinação de políticas locais. Neste contexto, Keating, querendo ir além da noção muito restrita de "Growth Machine", de John R Logan e Harvey L Molotch, desenvolve a noção de desenvolvimento de coalizão para dar conta de novas dinâmicas de desenvolvimento que emergem das/nas cidades. Estas são definidas como uma mobilização que ultrapassa as tradicionais divisões de classe e visam uma melhoria da competitividade de uma cidade, para atender o contexto estrutural atual.

Keating termina seu livro fazendo um convite para novas políticas urbanas progressistas, visando reconciliar a capacidade de governar com o pluralismo, o crescimento e a justiça social. Ele ressaltou a importância de um conceito ampliado do espaço público dentro de um sistema de valores coletivos.

Além disso, ele solicita a criação de estruturas políticas mais abertas e a integração das políticas urbanas locais e nacionais, permitindo, entre outras coisas, reduzir a dependência dos governos locais do setor privado. Ao fazê-lo, sua concepção de assemelha de uma concepção liberal clássica (Alexis de Tocqueville), querendo reconciliar o desenvolvimento econômico e as políticas sociais. Assim, Keating defende o desenvolvimento de uma cultura urbana, de uma urbanidade, que responderia melhor a uma concepção metropolitana que, em si, seria mais capaz de satisfazer as exigências da reestruturação em curso.

Um dos elementos interessantes é que Keating, ao longo de seu livro, refere-se a vários estudos e concepções relacionadas com múltiplas dimensões da política urbana. Em particular, ele põe em questão as teorias da escola do "Public Choise" (Eamonn Butler), muito focada em uma concepção individualista e reducionista da dinâmica política. Além disso, à luz das várias experiências urbanas examinadas, o livro oferece uma visão sobre algumas questões fortemente presente no Canadá, como a anexação dos subúrbios de Toronto.

No entanto, sua abordagem metodológica estruturada sobre uma análise temática simultânea para os quatro países nem sempre permite construir uma visão geral das políticas urbanas de cada país. Teria sido adequado fazer um resumo analítico para cada país afim de melhor destacar as diferenças entre eles, bem como as implicações comuns. Além disso, em nosso ponto de vista, o Canadá é parente pobre na análise comparativa, porque às vezes é difícil identificar a especificidade das políticas urbanas em comparação com outros países.

Finalmente, a abordagem comparativa de Keating é esclarecedora e permite localizar corretamente as diferentes facetas da política urbana, mas, acima de tudo, mostra que os governos locais ainda têm um papel a desempenhar no desenvolvimento urbano. Seu apelo no final do livro é sem dúvida interessante, mas como muitos, devemos questionar se é realmente possível reconciliar os interesses privados e coletivos, mesmo no âmbito da política urbana.

Tomás Antonio Moreira

Universidade de São Paulo. Instituto de Arquitetura e Urbanismo.

CV: http://lattes.cnpq.br/7348817908541292 